Acta vet. scand. $1970,11,268-282$.

From the National Veterinary Institute, Stockholm, Sweden.

\title{
POISONING IN FERRETS BY TISSUES OF ALKYL MERCURY-FED CHICKENS
}

By

E. Hanko, K. Erne, H. Wanntorp† and K. Borg

Already several years ago investigations at the National Veterinary Institute demonstrated the occurrence of a widespread alkyl mercury poisoning in terrestrial Swedish wildlife, particularly in seed-eating and predatory birds and also in predatory mammals (Borg 1958, Borg et al. 1965, 1966, 1969). Convincing evidence indicated alkyl mercury-based seed-dressings to be the predominant source of the poisonings.

For the predatory birds and mammals involved the main source undoubtedly was the prey animals, since other sources such as atmospheric and water-borne mercury could largely be excluded; predatory birds do not normally take any water. Considering the feeding habits of the predatory animals, the mercury ingested presumably derived essentially from the tissues rather than from the digestive tract of the prey animals. Therefore, the poisonings observed in predatory animals might be regarded as truly secondary.

The purpose of the present investigations was to provide experimental evidence for the transfer of toxicity along the food chain, alkyl mercury-treated seed $\rightarrow$ seed-eating bird $\rightarrow$ predatory mammal, and further to study the clinical course, patho-anatomical features and mercury tissue distribution of secondary alkyl mercury poisoning in a mammal. To this end, methyl mercury-dressed wheat was fed to chickens, and after sacrifice musculature (and some liver) of the chickens were fed to ferrets. 


\section{EXPERIMENTAL AND RESULTS}

\section{The primary mercury source}

Wheat seed commercially treated with a liquid formulation of methyl mercury dicyandiamide to give an expected mercury content of about $8 \mathrm{mg} / \mathrm{kg}$ was obtained through a regular supplier. Before feeding, the dressed wheat was mixed with a standard feed supplement to a few per cent. On analysis of nine samples of the finished feed, the mercury content was found to vary between 5.9 and 14.0 (average 8.2 ) $\mathrm{mg} / \mathrm{kg}$. In the calculations below, the diet was considered to contain $8 \mathrm{mg} / \mathrm{kg}$ of mercury.

\section{The secondary mercury source}

Two groups of about one year old chickens were fed the mercury containing feed described, the feed and water being freely accessible throughout the experiment.

In the first group ( 50 chickens, White Leghorn, about $1.4 \mathrm{~kg}$ ) the feeding proceeded for 40-44 days (September-October, 1965) and in the second (44, Rhode Island, about $1.7 \mathrm{~kg}$ ) for $35-38$ days (February-March, 1966). The estimated average daily food intake in the two groups was about 80 and $90 \mathrm{~g}$ per animal, respectively, corresponding to an average mercury intake of about 0.46 and $0.42 \mathrm{mg} / \mathrm{kg} /$ day, or a total of 28 and $27 \mathrm{mg}$ per animal, respectively. After the feeding period the animals were immediately sacrificed. Skeletal muscle and liver were secured and stored at $-20^{\circ} \mathrm{C}$ until required. In all, approximately. $45 \mathrm{~kg}$ of muscle and $6 \mathrm{~kg}$ of liver were obtained (roughly equal amounts from both groups).

No clinical signs of poisoning were seen in any of the chickens during the feeding period. Eggs were not laid.

The (total) mercury contents of the chicken muscle and liver (and of tissues of the ferrets (see below)) were determined by neutron activation analysis according to Westermark \& Sjöstrand (1960) and Sjöstrand (1964) and the methyl mercury contents by gas chromatography according to Westöö $(1966,1967)$. (The analyses were performed in cooperation with the Isotope Techniques Laboratory, Inc., Stockholm). The results are summarized in Table 1. All values refer to undried samples.

From the analytical data the overall average mercury content of the chicken muscle was calculated as about $10 \mathrm{mg} / \mathrm{kg}$. For the 
T a b l e 1. Total mercury and methyl mercury levels (wet weight) in tissues of chickens fed mercury-dressed wheat (average mercury content $8 \mathrm{mg} / \mathrm{kg}$ ) for $35-44$ days. Number of samples analyzed given within parenthesis.

\begin{tabular}{|c|c|c|c|c|}
\hline \multirow[t]{2}{*}{ Tissue } & \multicolumn{2}{|c|}{$\begin{array}{l}\text { Total mercury } \\
\mathrm{mg} / \mathrm{kg}\end{array}$} & \multicolumn{2}{|c|}{$\begin{array}{l}\text { Methyl mercury (as } \mathrm{Hg} \text { ) } \\
\text { per cent of total } \mathrm{Hg}\end{array}$} \\
\hline & average & range & average & $\overline{\text { range }}$ \\
\hline Chest muscle, White Leghorn & 12 & $7.3-18.6(11)$ & 111 & $92-119(6)$ \\
\hline$川 \quad, \quad$, Rhode Island & 8 & $5.9-10.9(10)$ & 94 & $65-123(5)$ \\
\hline Liver, mixed samples & 40 & $39-41 \quad(4)$ & 90 & $74-106(2)$ \\
\hline
\end{tabular}

liver the average value was $40 \mathrm{mg} / \mathrm{kg}$. It is evident that the tissue mercury was principally methyl mercury.

\section{Feeding experiments with ferrets}

Six adult female ferrets (polecat-ferrets, Mustela furo L. $X$ M. putorius L.) bred at this institute were used in the experiments, four (nos. 1-4) as experimental animals divided into two groups of two, and two (nos. 5 and 6 ) as controls. No. 6 was used primarily to provide complementary reference material for histological examination. The experimental animals were caged individually and fed the tissue of the treated chickens as described below, the feeding being continued until the death of the animals. Water supply was unrestricted. The controls were given tissues from untreated chickens.

Group $A$. The animals were given muscle and liver of the treated chickens supplemented with ordinary mink feed, the average daily ration offered during the first week containing $118 \mathrm{~g}$ of the muscle, $7 \mathrm{~g}$ of the liver and $75 \mathrm{~g}$ of the mink feed per animal. During the second week the proportions were 93, 7 and $50 \mathrm{~g}$ and thereafter 68,7 and $75 \mathrm{~g}$, respectively. From the third week on, a gradually decreasing proportion of the offered food was taken, from the fourth to fifth weeks practically nothing at all. As far as possible the refused food was collected and weighed.

Taking into account the amount of food refused, the total intake of chicken muscle and liver during this experiment was estimated as not more than 2500 and $200 \mathrm{~g}$ per animal, respectively, corresponding to a total mercury intake of at most $33 \mathrm{mg}$ per animal. 
Group $B$. These animals received the chicken muscle and liver incorporated to about 20 and $5 \%$, respectively, in a special diet, composed by K.-E. Kull for ferrets. During the first week the animals were offered $150 \mathrm{~g}$ daily of this diet and thereafter $100 \mathrm{~g}$ daily. As in the preceding experiment the animals refused the food to an increasing extent.

The maximum total intake of chicken muscle and liver was. estimated as 1000 and $250 \mathrm{~g}$ per animal, respectively, corresponding to a total mercury intake of at most $20 \mathrm{mg}$ per animal.

\section{Clinical symptoms}

The appetite of the experimental ferrets gradually decreased and during the eight to ten last days of life the animals practically took no food. Weakness of the extremities, trembling, twitching of the head and incoordination appeared within about two weeks in Group A and within about three weeks in Group B. Ataxia, paralysis and apathy gradually developed. At a later stage periods of excitation were seen, the animals yelling and creeping in narrow circles.

Death occurred within 35 and 36 days in Group $A$ and within 58 days in Group B. The controls were sacrificed after 37 days.

\section{Morphological changes}

Dead or killed animals were subjected to necropsy and specimens for histological examination taken from the liver, kidneys, spleen, pancreas, gonads, digestive tract, vulva, myocardium, skeletal muscles (extensor muscles of the thigh) and various parts of the central and peripheral nervous systems.

Tissues for histological examination were fixed in $10 \%$ aqueous formaldehyde. For staining haematoxylin-eosin, van Gieson, Luxol fast blue, Mahon and gallocyanine-chrome-alum according to Einarson were used. Frozen sections were stained with scarlet red for fat.

Gross and microscopical findings were similar in all experimental animals.

Gross findings. Loss of body weight was apparent in the experimental animals (Table 2).

The nutritional state was poor in one animal (no. 4) and moderate in one (no. 3) and body fat was consistently reduced in all the experimentals. In addition, there was a pronounced generalized muscular atrophy in the experimentals. 
T a b le 2. Body weight data, latency periods and survival times of ferrets fed chicken tissues containing physiologically incorporated methyl mercury.

\begin{tabular}{ccccc}
$\begin{array}{c}\text { Animal } \\
\text { no. }\end{array}$ & Sex & Body weight, kg & $\begin{array}{c}\text { Latency period } \\
\text { days }\end{array}$ & $\begin{array}{c}\text { Survival time } \\
\text { days }\end{array}$ \\
\cline { 2 - 3 } & before after & and & \\
\hline
\end{tabular}

Group $A$ (dietary methyl mercury $7 \mathrm{mg} / \mathrm{kg}$, as $\mathrm{Hg}$ )
1. $0676 / 67$
우
0.990
0.770
approx. 14
35
2. $0692 / 67$
$0.980 \quad 0.750$
approx. 14
36

Group $B$ (dietary methyl mercury $5 \mathrm{mg} / \mathrm{kg}$, as $\mathrm{Hg}$ )
3. $01470 / 67$
$q$
0.940
0.620
approx. 21
58
4. $01473 / 67$
approx. $0.9 \quad 0.450$
approx. 21
58

\section{Control}

5. $0700 / 67$

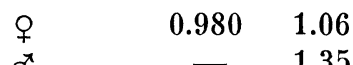

$\left.37^{\star}\right)$

6. $0196 / 69$

$\sigma^{x}$

1.35

*) Killed.

All experimental animals displayed a subacute cardiac ventricular dilatation, in two cases together with paleness of the myocardium.

In two animals the lungs were moderately congested, with emphysema and oedema.

In two animals (nos. 1 and 2 ) the liver was pale and tender but of normal size. Also the kidneys were pale. In no. 3 hepatic and renal congestion was apparent.

Haemorrhagic erosions of the gastric mucosa were seen in the animals of Group $A$, the ingesta consisting of a bloody mucous liquid. In the other animals the digestive tract appeared grossly normal.

In the animals in group B the vulva was enlarged, and of a whitish-grey colour.

No gross changes were seen in the central or peripheral nervous systems of any animal.

Mange of the ears (Otodectes cynotis) occurred sparsely in three experimental and one control animal. Bacteriological examination was negative in all animals.

Microscopic findings. Slight to marked, diffuse fatty degeneration was seen in the skeletal muscles of two and in the myocardium of three animals. Fatty degeneration of the liver cells and of the renal proximal tubular epithelium was seen in all 
experimental animals. In one animal there was an acute waxy muscular degeneration with disintegration of the fibrils.

Hypoplasia of the lymphatic tissue of the spleen was observed in the animals of Group $A$; the cell content of the red pulpa was reduced and the trabeculae were prominent (Figs. 1 and 2 ).

Superficial haemorrhagic erosions of the gastric mucosa and slight round-cell infiltration of the intestinal mucosa were noted in two animals.

No definite changes were seen in the vulva wall except for slight connective tissue proliferation of the subcutis.

The ovaries of the animals of Group B were examined. In no. 3 one fresh luteal body, one graafian follicle and multiple primordial follicles were found, while some follicles apparently had ceased developing. In no. 4 there were multiple primordial and isolated secondary follicles but no graafian follicles or corpora lutea.

No changes were noticed in the pancreas.

The most conspicuous microscopical changes were those of the peripheral and central nervous systems, the changes being similar in all experimental animals.

In peripheral nerves (Plexus brachialis, N. ischiadicus and spinal nerves) there was a focal myelin degeneration characterized by reduced stainability, vacuolization and partial to complete disappearance of the myelin. Further, the axis cylinders were enlarged and focally disintegrated, forming fusiform or irregular fragments (Figs. 3 and 4 ).

In the cerebellar medulla and in the pons, areas of reduced stainability, demyelination and vacuolization occurred together with nerve cell degeneration. The latter was characterized by chromatolysis beginning around the nucleus and in advanced cases involving marginal vacuolization, homogenization of the cytoplasm and peripheral agglutination of highly stainable Nissl granules. Sometimes, the neuron degeneration was so severe that only intensely stainable pycnotic rests or vacuolized shadows of poor stainability remained. Chromatolysis was often accompanied by enlargement of the nucleoli followed by pycnosis and karyolysis (Figs. 5 and 6 ). These lesions were most prominent at the base of the arbor vitae but occurred in the lamellae too. In addition, slight gliosis was noted, predominantly in the pons.

In one animal (no. 1) a focal, nonpurulent lymphohistiocytic encephalitis with isolated perivascular cellular cuffings was observed. 

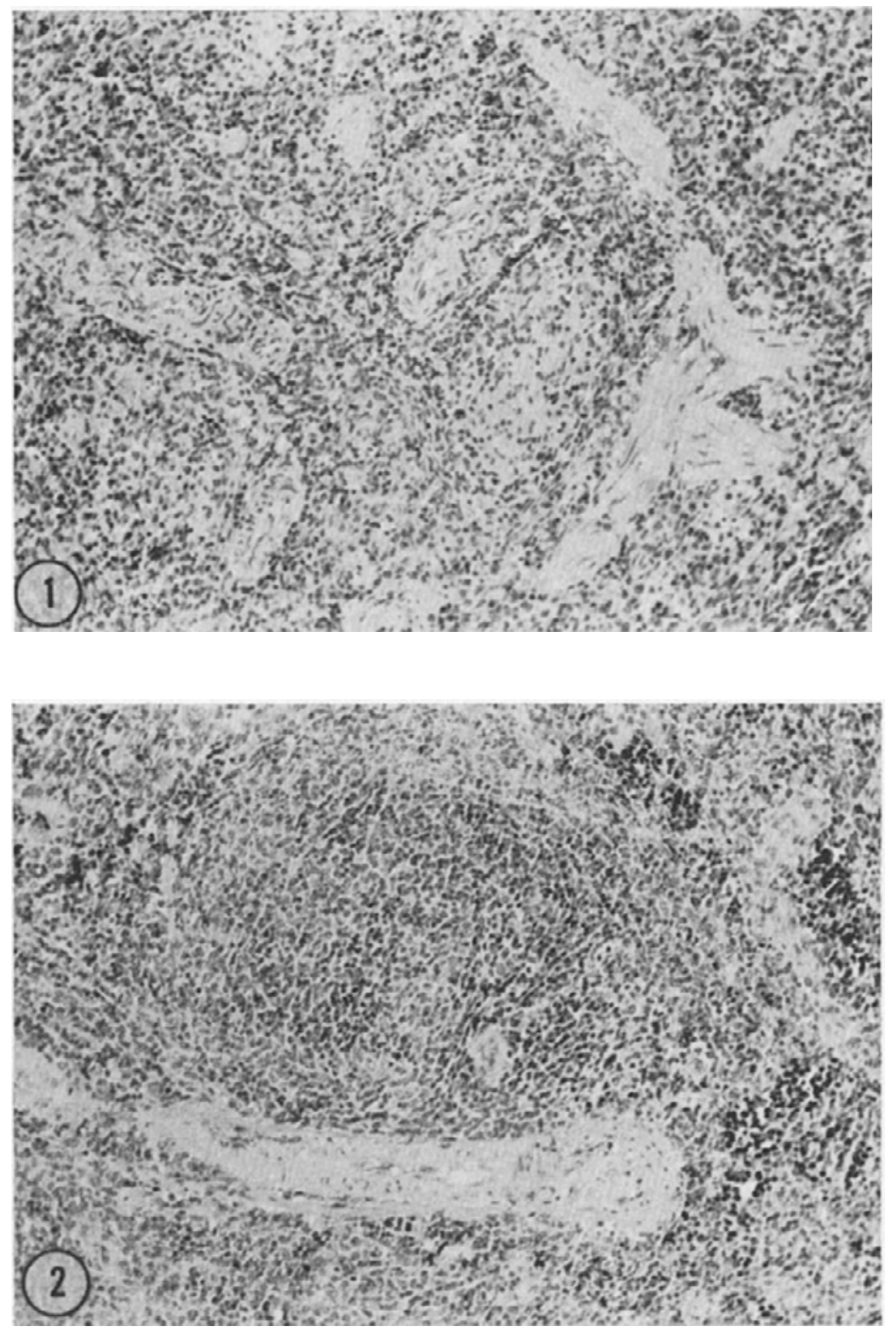

F i g u r e 1. Spleen (ferret no. 2), hypoplasia of lymphatic tissue, $\mathrm{H}-\mathrm{E}, \times 150$.

F i g u r e 2. Spleen (ferret no. 5), normal, H-E, $\times 150$. 

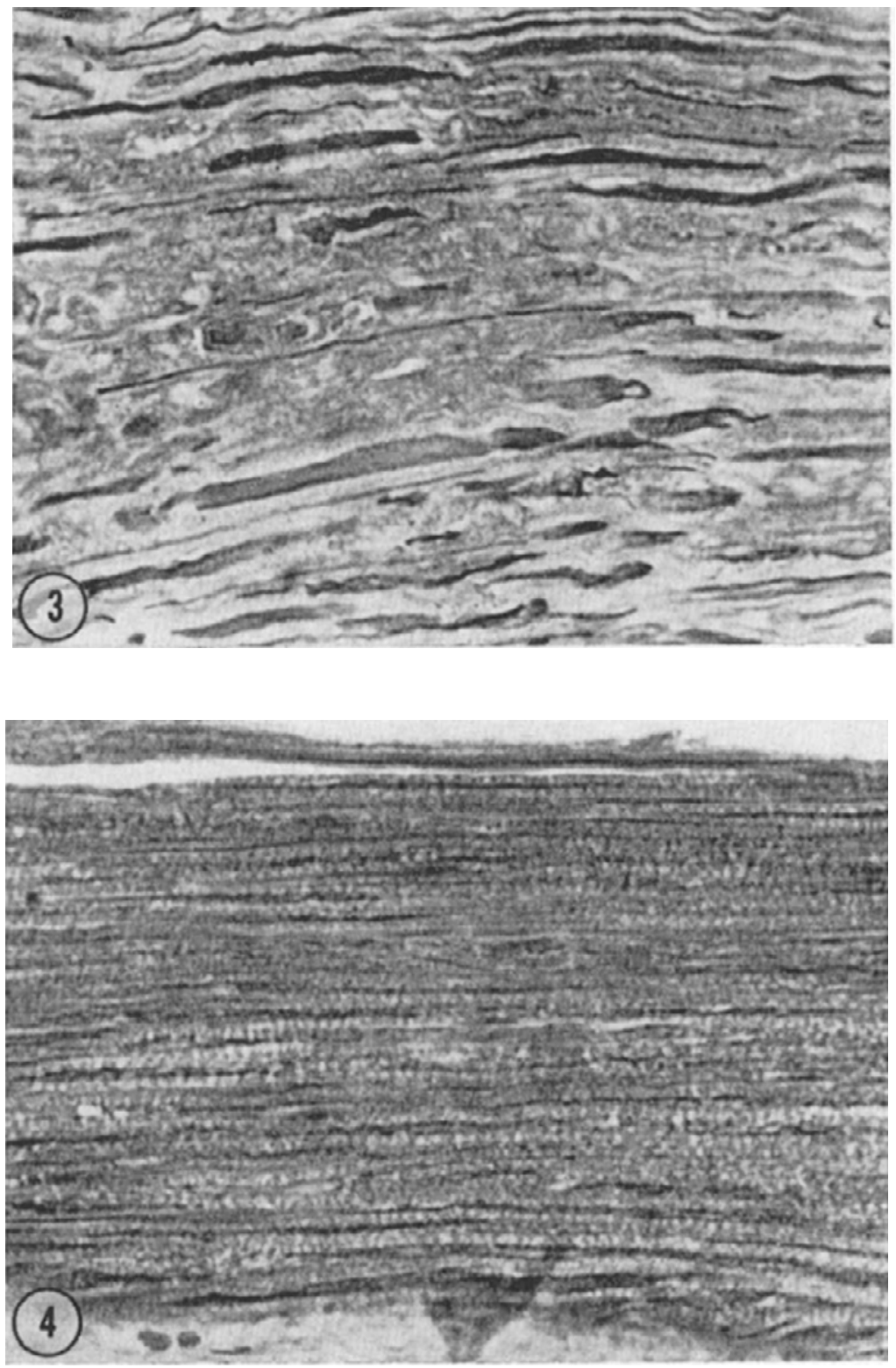

Figure 3. Peripheral nerve (ferret no. 2), myelin degeneration, Luxol fast blue, $\times 500$.

F i g u r 4. Peripheral nerve (ferret no. 6), normal, Luxol fast blue, $\times 500$. 

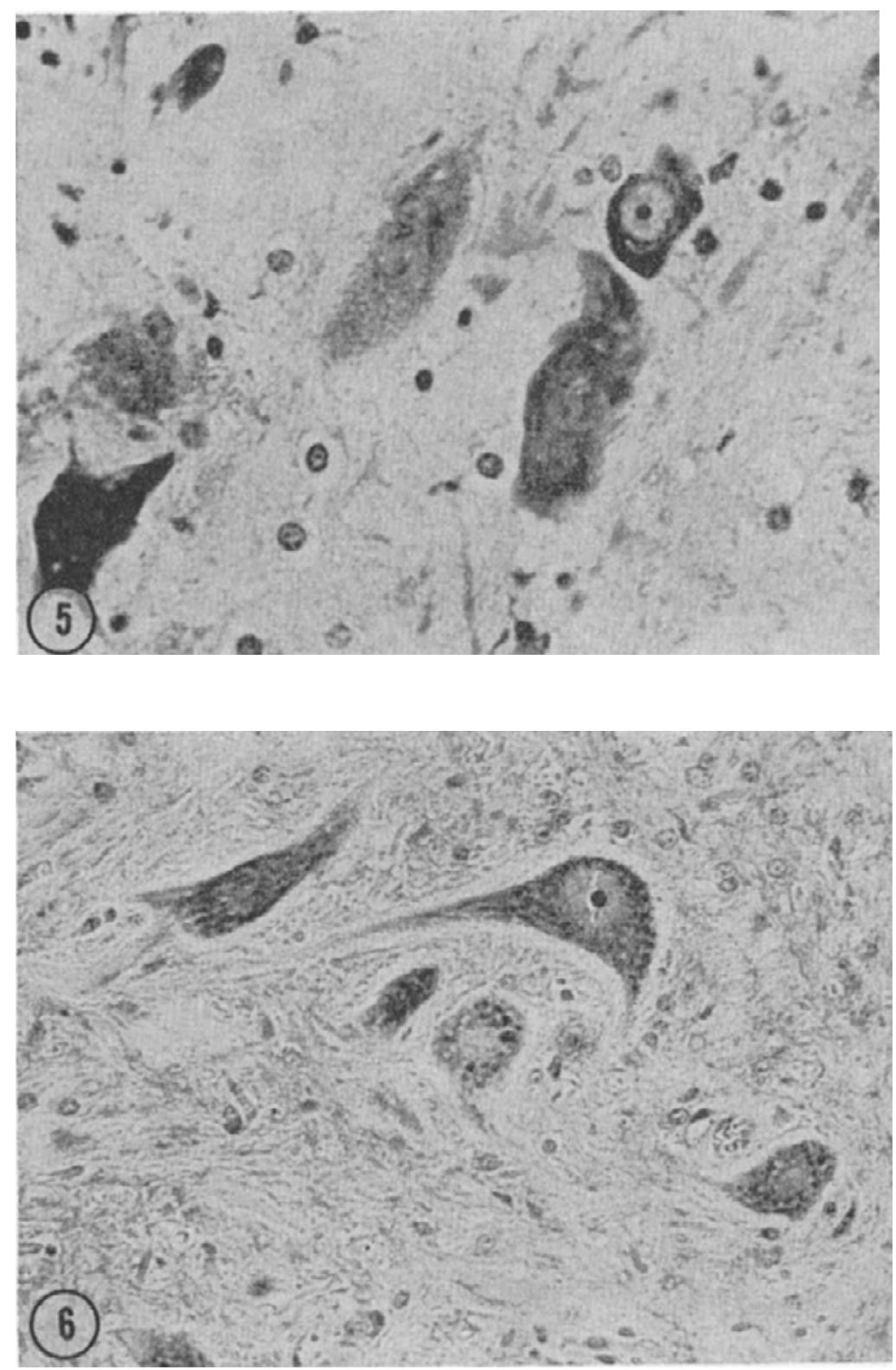

Fig u r e 5. Pons (ferret no. 3), nerve cell degeneration, gallocyaninechrome-alum (Einarson), $\times 500$.

Fig u r e 6. Pons (ferret no. 5), normal, gallocyanine-chrome-alum (Einarson), $\times 500$. 
The cerebrum displayed a slight focal myelin degeneration. Further, a very slight nerve cell degeneration was seen.

Slight focal demyelination and neuron degeneration were also seen in the spinal cord, mainly in the ventral horns.

\section{Mercury levels}

The total and methyl mercury levels found in tissue samples of the experimental and of one of the control animals are summarized in Table 3.

Table 3. Total and methyl mercury tissue levels in ferrets fed chicken tissues containing physiologically incorporated methyl mercury.

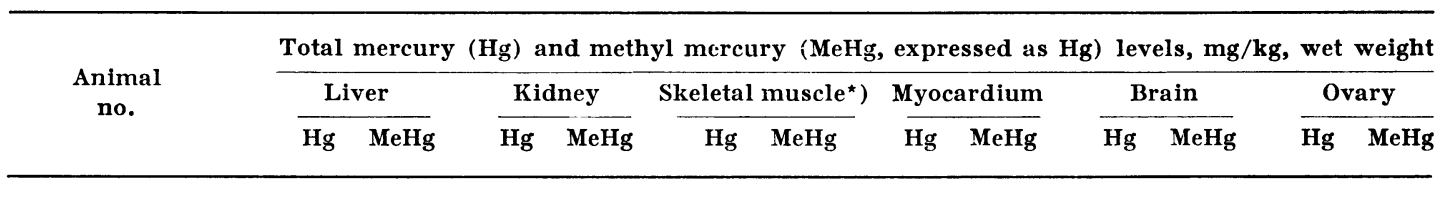

Group A (dietary methyl mercury $7 \mathrm{mg} / \mathrm{kg}$, as $\mathrm{Hg}$ )
1. $0676 / 67$
$57 \quad 45$

$59 \quad 35$
$35 \quad 23$
$-\overline{-}$
$35 \quad 34$
2. $0692 / 67$

$\begin{array}{llll}64 & 44 & 87 & 50\end{array}$

$43 \quad 35$
39

Group $B$ (dietary methyl mercury $5 \mathrm{mg} / \mathrm{kg}$, as $\mathrm{Hg}$ )

$\begin{array}{rlrlllllllllll}\text { 3. } & \text { O } 1470 / 67 & 39 & 28 & 63 & 47 & 28 & 12 & 35 & 15 & 26 & 33 & 16 & - \\ \text { 4. } & \text { O } 1473 / 67 & 55 & 35 & 67 & 30 & 31 & 32 & 20 & 18 & 7 & 14 & 49 & -\end{array}$

\section{Control}

\begin{tabular}{lllllllllllllllllll}
5. & 0 & $700 / 67$ & 1.8 & 0.8 & 2.7 & 0.6 & 0.9 & 0.5 & - & - & 0.4 & 0.5 & - & - \\
\hline
\end{tabular}

*) Extensor muscles of the thigh.

**) Uncertain because of small sample weight.

\section{DISCUSSION}

The course of the poisoning in the ferrets was remarkably rapid when compared with the chickens with remained clinically healthy throughout the feeding period. The dietary alkyl mercury levels and the duration of feeding were comparable in the two sets of experiments, although there might have been differences in availability of the mercury in the seed and in the animal tissues, thereby causing possible differences in absorption rate (see below).

The poisoning in the ferrets was attended by a striking loss of body weight which might be largely attributable to the pronounced and regularly occurring muscular atrophy. Although 
not being pathognomonic for alkyl mercury poisoning, muscular atrophy has been associated with such poisoning also in other animal species (Borg et al. 1965, 1969, 1970).

Other gross changes observed in the poisoned animals were largely nonspecific and certain changes, such as those of the vulva, aetiologically unclear and possibly not related to the alkyl mercury exposition.

The most conspicuous microscopical changes were, except for fatty degeneration of parenchymatous organs, those of the central and peripheral nervous systems which afforded a morphological basis for the predominantly neurological clinical signs. The lesions were most pronounced in the cerebellum and the medulla oblongata. It might be noted that marked lesions in the occipital lobes of the cerebrum as reported for primates (Nordberg et al. to be published) were not observed.

Notable was lymphatic hypoplasia of the spleen in two animals. In this connection attention may be drawn to the marked accumulation of mercury in the adrenals of mice injected with ethyl mercury (Berlin \& Ullberg 1963).

The mercury distribution pattern in the dead ferrets (Table 3 ) was of the same type as that observed in other species after alkyl mercury administration (Ulfvarson 1962, Berlin \& Ullberg, Gage 1964, Tejning 1967, Swensson \& Ulfvarson 1968 a, b), high levels being found in the liver, kidneys and central nervous system. The kidney levels did not significantly exceed those of the liver. In rats high kidney-liver ratios have been found (Gage), while in birds the reverse is often seen (Borg et al. 1965, 1969, 1970, Tejning 1967). The mercury levels of the skeletal muscle were high, the muscle-liver ratio being approximately $0.5-0.7$, as compared with $0.2-0.4$ usually seen in birds (Smart \& Lloyd 1963, Borg et al. 1965, 1969, 1970, Tejning). The marked mercury accumulation in the gonads should be considered as physiologically important in the light of the established genetic effects of alkyl mercury (cf. Ramel 1967). Except for one animal (no. 4) with a low value, the brain levels were comparable to those of the skeletal musculature, or of the order of $30 \mathrm{mg} / \mathrm{kg}$.

The analytical evidence indicated that methyl mercury constituted by far the major part of the tissue mercury in the ferrets, just as in the chickens. (In some instances the methyl mercury values exceeded the corresponding total mercury values (Tables 1 and 3 ), probably as a result of sample heterogeneity 
- total and methyl mercury were determined in separate portions of sample). Two important conclusions can be drawn from these findings. 1) An alkyl mercury compound may be able to pass a food chain without splitting of the carbon-mercury bond. 2) Physiological incorporation into animal tissues of alkyl mercury apparently does not impair its availability to carnivorous animals.

The mercury levels attained in skeletal muscle of the poultry (10 $\mathrm{mg} / \mathrm{kg}$ on an average) seem somewhat low compared with the results of other feeding experiments in birds with alkyl mercury (Smart \& Lloyd 1963, Borg et al. 1965, 1969, 1970, Tejning). Particularly when considering that in the present experiments, unlike in the others mentioned, no mercury was excreted with the eggs and probably only small amounts with the plumage (the birds were not moulting during the experimental period), higher tissue levels could be anticipated. One possible reason for the low values is that a steady state of accumulation has not been attained during the relatively short feeding period (five to six weeks), as might be inferred by analogy from the results of Smart \& Lloyd and Tejning. The differing mercury levels found in the White Leghorns and the Rhode Islands might, at least in part, be related to the different proportions in the two breeds of dark and pale chest muscle. As Bäckström (1969) has shown in experiments with quail, the dark (external) chest muscle retains alkyl mercury more effectively than the pale (internal) type. Taking the mercury content of the chicken feed as $8 \mathrm{mg} / \mathrm{kg}$ (and considering the different water contents of the feed and chicken muscle), the concentration factor for chicken muscle may be calculated as about 2 .

In the ferrets, on the other hand, the mercury accumulation was pronounced. From dietary mercury levels of 7 and $5 \mathrm{mg} / \mathrm{kg}$ for Groups A and B, respectively, muscle levels of 40 and 30 $\mathrm{mg} / \mathrm{kg}$ were built up, thus corresponding to a concentration factor of about 6. Comparable results were obtained by us in experiments with chickens and goshawks (Borg et al. 1970). The lower degree of accumulation in the chicken experiment probably may be attributed to a lower absorption rate of alkyl mercury from seed than from animal tissues. Incomplete absorption of alkyl mercury from treated seed was noted by $T e j-$ ning.

The accumulation of mercury, and the secondary poisoning 
as demonstrated in these experiments may have important ecological consequences. Thus, during natural conditions the accumulation is likely to be enhanced by the selection mechanisms operating in natural food chains. The selection by a predator of prey animals already debilitated by mercury poisoning undoubtedly will increase the hazards to the predator considerably. Important in this connection is further the fact that the muscle mass of a prey animal will contain the major part of the body mercury. According to Tejning about $75 \%$ of the body mercury in chickens is to be found in the muscles.

\section{REFERENCES}

Berlin, M. \& S. Ullberg: Accumulation and retention of mercury in the mouse, III. An autoradiographic comparison of methylmercuric dicyandiamide with inorganic mercury. Arch. environm. Hlth 1963, 6, 598-601.

Borg, K.: Inverkan av betat utsäde på viltfaunan. (Effects of dressed seed in game birds). VIII Nord. Vet.-möte, Helsingfors 1958, $394-400$.

Borg, K., H. Wanntorp, K. Erne \& E. Hanko: Kvicksilverförgiftningar bland vilt i Sverige. (Mercury poisoning in Swedish wildlife). Mimeographed report. National Veterinary Institute, Stockholm 1965.

Borg, K., H. Wanntorp, K. Erne \& E. Hanko: Mercury poisoning in Swedish wildlife. J. appl. Ecol. 1966, 3, Suppl., 171-172.

Borg, K., H. Wanntorp, K. Erne \& E. Hanko: Alkyl mercury poisoning in terrestrial Swedish wildlife. Viltrevy 1969, 6, 301-379.

Borg, K., K. Erne, H. Wanntorp \& E. Hanko: Experimental secondary methyl mercury poisoning in the goshawk (Accipiter g. gentilis L.). Environ. Poll. 1970, 1, 93-106.

Bäckström, J.: Artsskillnader i kvicksilverdistributionen Mus — fågel - fisk. (Species differences in mercury distribution Mouse bird - fish). Nord. hyg. T. 1969, 50, 130-134.

Gage, J. C.: Distribution and excretion of methyl and phenyl mercury salts. Brit. J. industr. Med. 1964, 21, 197-202.

Nordberg, G. F., M. H. Berlin \& C. A. Grant: Methyl mercury in the monkey - autoradiographical distribution and neurotoxicity. To be published.

Ramel, C.: Genetic effects of organic mercury compounds. Oikos 1967, 18, Suppl. 9, 35-36.

Sjöstrand, B.: Simultaneous determination of mercury and arsenic in biological and organic materials by activation analysis. Analyt. Chem. 1964, 36, 814-819.

Smart, N. A. \& M. K. Lloyd: Mercury residues in eggs, flesh and livers of hens fed on wheat treated with methyl mercury dicyandiamide. J. Sci. Food Agric. 1963, 14, 734-740. 
Swensson, $\AA$. \& U. Ulfvarson: Distribution and excretion of various mercury compounds after single injections in poultry. Acta pharmacol. (Kbh.) 1968 a, 26, 259-272.

Swensson, $\AA$. \& U. Ulfvarson: Distribution and excretion of mercury compounds in rats over a long period after a single injection. Acta pharmacol. (Kbh.) 1968 b, 26, 273-283.

Tejning, S.: Biological effects of methyl mercury dicyandiamidetreated grain in the domestic fowl Gallus gallus L. Oikos 1967, 18, Suppl. 8, 1-116.

Ulfvarson, $U .:$ Distribution and excretion of some mercury compounds after long term exposure. Int. Arch. Gewerbepath. Gewerbehyg. $1962,19,412-422$.

Westermark, T. \& B. Sjöstrand: Activation analysis of mercury. Int. J. appl. Radiat. 1960, 9, 1-15.

Westöö, G.: Determination of methylmercury compounds in foodstuffs. I. Methylmercury compounds in fish, identification and determination. Acta chem. scand. 1966, 20, 2131-2137.

Westöö, G.: Determination of methylmercury compounds in foodstuffs. II. Determination of methylmercury in fish, egg, meat, and liver. Acta chem. scand. 1967, 21, 1890-1900.

\section{SUMMARY}

Chickens were fed alkyl mercury-dressed wheat (mercury content about $8 \mathrm{mg} / \mathrm{kg}$ ) for $35-44$ days and were then immediately sacrificed. No signs of untoward effects were observed. Muscle of the chickens, and a minor proportion of liver, were fed to two groups of two ferrets (Mustela furo L. $\times$ M. putorius L.), the mercury content of the diet being 7 and $5 \mathrm{mg} / \mathrm{kg}$, respectively. The ferrets of the first group died after 35 and 36 days and those of the second after 58 days.

The experimental ferrets showed a marked weight loss, attributable to muscular atrophy in addition to a reduced food intake. Clinical signs appeared in two to three weeks and were primarily neurological such as ataxia, trembling and paralysis. The signs could be correlated with pronounced degenerative changes of the central and peripheral nervous systems involving mainly the cerebellum and peripheral nerves and, to a lesser extent, the cerebrum and the spinal cord. Hypoplasia of the lymphatic tissue of the spleen and degeneration of the graafian follicles were seen as well.

High mercury levels were found in the kidneys, liver and brain and also in skeletal muscle and the gonads of the ferrets (Table 2). Methyl mercury constituted the major part of the tissue mercury in the ferrets (as well as in the chickens).

The results provide direct evidence of the transfer and accumulation of alkyl mercury in a toxic form through a food chain. The ecological implications are discussed. 


\section{SAMMANFATTNING}

Förgiftning av iller med kött av alkylkvicksilverutfodrade höns.

Tamhöns utfodrades med alkylkvicksilverbetat vete (kvicksilverhalt ca. $8 \mathrm{mg} / \mathrm{kg}$ ) under 35 —44 dagar och avlivades omedelbart därefter. Inga tecken på förgiftning iakttogs.

Två grupper (vardera på 2 djur) av iller utfodrades med muskulatur (och en ringa tillblandning av lever) från hönsen. Den genomsnittliga kvicksilverhalten $i$ fodret hos de två grupperna var 7 resp $5 \mathrm{mg} / \mathrm{kg}$. Djuren i den första gruppen dog efter 35 och 36 dagar och de $\mathrm{i}$ den andre efter 58 dagar.

En påtaglig viktsförlust noterades hos försöksillrarna, vilken kunde tillskrivas skelettmuskelatrofi $i$ förening med nedsatt foderintag. I övrigt iakttogs, med början efter $2-3$ veckor, huvudsakligen förgiftningssymptom av neurologisk art, såsom ataxi, darrningar och förlamningar. Symtomen kunde korreleras med degenerativa förändringar främst $i$ lillhjärna och perifera nerver men även i storhjärna och ryggmärg. Därjämte iakttogs hypoplasi av mjältens lymfatiska vävnad och follikeldegeneration i ovarierna.

Höga kvicksilverhalter påvisades i njurar, lever och hjärna och även i skelettmuskulatur och gonader hos försöksillrarna (Tabell 2). Kvicksilverinnehållet $i$ vävnaderna hos såväl illrar som höns visades bestå huvudsakligen av metylkvicksilver.

Försöksresultaten ger positivt belägg för att alkylkvicksilver kan passera en näringskedja under anrikning och med till synes bibehållen toxicitet. De ekologiska konsekvenserna diskuteras.

(Received October 20, 1969). 